\title{
TA INNA. ŚLADY KOBIECEGO „JA" W REPORTAŻACH ILONY WIŚNIEWSKIEJ
}

https://doi.org/10.25312/2451-2737.14/2019_03ezh

\section{StreszCzenie}

Artykuł ma na celu przedstawienie reportaży Ilony Wiśniewskiej, dokumentujących jej podróż na północ Europy. Przedmiotem badania są przede wszystkim te fragmenty tekstów, które ukazują relacje dziennikarki z Innym. Jako że kobiecy reportaż podróżniczy nie doczekał się jeszcze gruntownego omówienia, głównym celem szkicu jest opisanie specyfiki tej formy, a także przedstawienie pozostawionych przez autorkę w książkach, takich jak Białe, Hen oraz Lud śladów kobiecej tożsamości.

Słowa kluczowe: reportaż kobiecy, reportaż podróżniczy, Ilona Wiśniewska, Spitsbergen, Inny

\section{The Other. Traces of female identity in llona Wiśniewska's reportage Summary}

This article presents Ilona Wiśniewska's reportage of her journey to the northern part of Europe. Special attention is paid to those fragments of the author's texts that show her relations with the 'Other'. As women's travel reportage is not yet sufficiently discussed, the article focuses on describing elements typical of this genre. The article also presents the traces of female identity visible in Biate (White), Hen (Far Away) and Lud (People).

Keywords: women's reportage, travel reportage, Ilona Wiśniewska, Spitsbergen, Other 
Na gruncie badań literaturoznawczych i medioznawczych teoretyczna refleksja nad reportażem prowadzona jest zazwyczaj w sposób zasadniczo nieuwzględniający wpływu płci piszącego na kształt wychodzącej spod jego pióra publikacji. Dlatego analiza pozostawionych przez dziennikarki śladów w tekście, jak również tematyzowanie „kobiecości” przekazów medialnych, ograniczało się dotychczas najczęściej do badania przypisywanego autorkom konwencjonalnego zestawu interesujących je zagadnień; zdecydowanie rzadziej zaś do analizy poetyki pisanych przez nie tekstów (Wrzeszcz, 2013, Kuros-Kowalska, 2015; Stelingowska, 2018). Tymczasem, jak twierdził Ryszard Kapuściński, redukowanie w reportażu instancji nadawczej tekstu li tylko do roli milczącego pośrednika wydaje się zabiegiem całkowicie nieuzasadnionym: „Reporter jest nie tylko tubą, do której wstrzykuje się dziesiątek liczb, nazwisk i opinii. Także chciałby coś czasem powiedzieć" (Kapuściński, 2016: 63-64).

Niniejszy szkic poświęcony jest omówieniu pozostawionych w reportażu śladów autorskiej obecności, będących z jednej strony sui generis sygnaturą autora, z drugiej zaś formą jego tekstowego uobecnienia; sposobem wytwarzania tożsamości w akcie pisania reportażowego tekstu. Choć analizowany tu gatunek - jako przekaz stricte dziennikarski - ma pełnić przede wszystkim funkcję informacyjną, mimo pozornego nawet dążenia do obiektywizmu i przyjmowania przez reporterów allotropicznej perspektywy, współcześnie ciąży on w kierunku narracji silnie spersonalizowanej. W wychodzących spod piór wielu dziennikarek (i dziennikarzy) tekstach dostrzegalna jest - posługując się określeniem Małgorzaty Czermińskiej - obecność żywiołu autobiograficznego (Czermińska, 1982: 223). Zabieg ten z jednej strony uwiarygodnia i uprawdopodabnia przekaz jako zapis konkretnego, indywidualnego doświadczenia, z drugiej - znacząco redukuje dystans pomiędzy czytelnikiem a wydarzeniem. W celu zobrazowania nakreślonego tu problemu w niniejszym szkicu analizie poddane zostaną tomy reportażowe autorstwa Ilony Wiśniewskiej, w których - jak wstępnie zakładam - wyraźnie dostrzegalne są cechy charakterystyczne dla pisarstwa kobiecego.

Jak zauważa Ewa Nawrocka, „[...] każda relacja z podróży staje się tekstem autobiograficznym [...]" (Nawrocka, 2002: 49). Myśl tę podziela Beata Walęciuk-Dejneka, pisząc, że „podróż bywa fragmentem biografii” (Walęciuk-Dejneka, 2016: 102). Wydaje się, że niezwykle często eksponujące sam akt pisania prace Wiśniewskiej w pełni realizują to założenie. Analizując tomy: Białe (Wiśniewska, 2014), Hen (Wiśniewska, 2016) oraz Lud (Wiśniewska, 2018), warto zastanowić się, czy na ich przykładzie możliwe jest wyodrębnienie zestawu cech charakterystycznych dla "kobiecego" dyskursu reportażowego (Kaliszewski, Żyrek-Horodyska, 2019). W tym celu konieczne jest zwrócenie się przede wszystkim w kierunku genologii dziennikarskiej, każącej w pierwszej kolejności widzieć w reportażu literackim nie tyle przekaz quasi-artystyczny, ile dokumentarny zapis zdarzeń. Artur Rejter podkreśla, że „[...] reportaż (w tym reportaż podróżniczy) jest przede wszystkim gatunkiem użytkowym" (Rejter, 2000: 32), ma zatem w pierwszej kolejności przekazywać fakty, nie emocje. Interesującą kwestią wydaje się więc to, w jaki sposób w odniesieniu do omawianej tu formy, dążącej do stworzenia możliwie najwierniejszej tekstowej reprezentacji 
rzeczywistości, scharakteryzowana mogłaby zostać poetyka kobiecego wariantu twórczości reportażowej, wpisująca się w nurt określany przez Hélène Cixous jako écriture féminine (Cixous, 1993: 147).

\section{Kobieca perspektywa w reportażu}

Wyszczególniona przeze mnie w tytule niniejszego szkicu kategoria śladu kobiecego „ja” jest nawiązaniem do ustaleń Ryszarda Nycza, który, pisząc o „śladzie obecności”, zanotował, iż jest on czymś, co „[...] daje znać o sobie i natychmiast znika w nieuchronnej mediatyzacji" (Nycz, 1981: 205). Ta efemeryczna wręcz konstrukcja zdaje się doskonale opisywać paradoksalną sytuację, w jaką uwikłany jest (męski i kobiecy) podmiot tekstowy we współczesnym reportażu literackim. Z jednej strony, pozostaje on bowiem na mocy typowej dla gatunków non-fiction konwencji utożsamiony z autorem zewnętrznym (dziennikarzem), z drugiej zaś - pozostaje przecież li tylko utrwalonym w materii tekstu śladem piszącego, "konstruktem” zredukowanym do roli pośrednika między czytelnikiem a wydarzeniem, swoistą „tekstualizacją realnego" (Nycz, 2001: 13). Zauważyć można, że w omawianym tu gatunku (a zwłaszcza w jego podróżniczej odmianie) kobiecy podmiot zwraca się często do czytelnika z pozycji Innego (Innej?), definiuje siebie poprzez relację z Innymi, w sposób szczególny akcentując swą obecność na scenie zdarzeń i odmienność tworzonej narracji od tej, która wyszła spod męskiego pióra.

W książce pt. Ten Inny Kapuściński zwrócił uwagę na to, że „określenia: Inny, Inni można rozumieć na wiele sposobów i używać w różnych znaczeniach i kontekstach, na przykład dla rozróżnienia płci, pokoleń, narodowości, religii itd." (Kapuściński, 2006: 9). Choć na kartach swych prac tę szeroką definicję inności reporter ograniczał najczęściej do kontekstu geograficznego, przeciwstawiając Europejczyków nie-Europejczykom, zasugerowana przez niego możliwość wykorzystania jej także w odniesieniu do płci wydaje się niewątpliwie warta rozważenia. Dotychczas pytanie, czy w tekście reporterskim pojawiają się ślady podmiotu kobiecego, a zatem (parafrazując formułę Kapuścińskiego) „tej Innej”, nie doczekało się jednoznacznej odpowiedzi. Reportaż domaga się bowiem zgoła odmiennej uwagi niż dzieło literackie; inne pełni także funkcje. Obserwowane w ostatnich latach wyraźne zbliżanie się tego gatunku do literatury każe jednak z nieco większą uwagą przyjrzeć się wspomnianej tu kwestii i raz jeszcze powrócić do uwag zanotowanych przez autora Cesarza.

Jak pisze Rosi Braidotti, „[...] kobieta jako «inna» jest prototypem tego wszystkiego, co zostało wykluczone ze sposobów myślenia, w których tworzy się reguły" (Braidotti, 2009: 256). Problem ten rozwinęła Maria Janion w książce pt. Kobiety $i$ duch inności (2006), w której badaczka spogląda na wybrane kobiece postaci literackie przez pryzmat takich zjawisk, jak szaleństwo czy wykluczenie. Do zagadnienia kobiecej inności nawiązał również Przemysław Czapliński w tytule szkicu Kobieta jako inny. Literatura 
wobec ponowoczesności (2010). Przywołany tu zestaw prac pozwala zauważyć, że uwaga badaczy koncentrowała się najczęściej wokół podmiotu dzieł literackich. Tymczasem w badaniach nad tekstami reportażowymi, wielokrotnie analizowanymi jako zapis „spotkania z Innym” (Kapuściński, 2004) w wielokulturowym świecie, punkt ciężkości kładziony był natomiast zazwyczaj na postać bohatera, nie zaś na osobę reportera czy reporterki.

Kobiecy reportaż podróżniczy zdaje się podejmować problematykę inności w dwojaki sposób. Jest on bowiem nie tylko próbą dotarcia do przedstawicieli odmiennej kultury, ale także rodzajem komunikatu zazwyczaj bardzo wyraźnie eksponującego kobiece doświadczenie w procesie gromadzenia i opracowywania informacji. Podejmując temat odmienności czy wykluczenia, autorka (jako Inna) sytuuje się nie „ponad” opisywaną rzeczywistością, lecz raczej „obok” niej; staje z nią - przywołując słynną formułę Emmanuela Lévinasa - niejako "twarzą w twarz". Jak zauważył myśliciel, „bycie obecnym przed twarzą, moje zwrócenie się ku Innemu, tylko wtedy może utracić właściwą spojrzeniu zachłanność, gdy zamienia się w szczodrość, która nie może przystąpić do Innego z pustymi rękami" (Lévinas, 2002: 41). Myśl tę trafnie podsumował Józef Tischner, twierdząc, że „inność jest wzajemna” (Tischner, 2004: 19). Współczesne reporterki-podróżniczki przychodzą do Innego bardzo często z własną historią, poszukując określonych paralel pomiędzy osobistymi doświadczeniami a sytuacją portretowanych postaci. W efekcie stają się często pełnoprawnymi bohaterkami tekstu, otwarcie eksponującymi swe odczucia i spostrzeżenia.

We współczesnym polskim reportażu literackim kobiecy głos słyszalny jest coraz wyraźniej. Obok prac takich uznanych już autorek, jak: Hanna Krall, Małgorzata Szejnert, Ewa Owsiany czy Lidia Ostałowska, na dziennikarski parnas wkraczają reporterki młodszej generacji, by wymienić tylko: Wiśniewską, Izę Michalewicz, Małgorzatę Rejmer, Justynę Kopińską czy Izę Klementowską. Dziennikarki te w swych książkach podejmują niezwykle szerokie spektrum tematyczne. We wprowadzeniu do opublikowanego w 2014 roku tomu pt. Odwaga jest kobieta, gdzie znajdujemy między innymi prace kilku spośród wymienionych tu autorek, czytamy:

Najpierw ostrzeżenie: czytanie tekstów z tego zbioru nie będzie fascynujące dzięki szalonej dramaturgii i gwałtownym zwrotom akcji. Bohaterki tych reportaży nie mieszkają w egzotycznych krajach, a reporterki, które im się przyglądają, nie szukają sensacji. Przedstawiają za to sprawy powszednie w zaskakujący sposób (Odwaga jest kobietą, 2014: 3).

Już nawet pobieżny przegląd tekstów opublikowanych we wspomnianym tomie pozwala zauważyć, że w pracach polskich reporterek przeważa problematyka społeczna, historyczna, obyczajowa, kulturalna. Zdecydowanie rzadziej spotykamy się dziś natomiast z pisywanym przez kobiety literackim reportażem podróżniczym, w którym zdaje się dominować męski głos. Fakt ten dziwić może zwłaszcza ze względu na długą i bogatą historię polskiego podróżopisarstwa kobiecego, które współcześnie nie znajduje jednak szczególnie wielu naśladowczyń (wyjąwszy może popularne trawelebryckie narracje autorstwa Beaty Pawlikowskiej czy Martyny Wojciechowskiej). 
Potwierdzenie faktu, że elementy genderowe zdają się w znacznym stopniu modelować nie tylko literaturę, ale także dyskurs reportażowy, znajdujemy w książce Piórem niewieścim. Z problemów prozy kobiecej dwudziestolecia międzywojennego autorstwa Ewy Kraskowskiej. Badaczka analizuje między innymi pojawiające się w interesującym ją okresie reportażowe teksty pisane przez kobiety. Omawiając dorobek takich autorek, jak: Wanda Melcer, Zofia Nałkowska czy Maria Kuncewiczowa, Kraskowska stara się wyodrębnić cechy charakterystyczne dla reportażu kobiecego, w którym „[...] przy okazji bardzo różnych tematów ujawniają się feministyczne zapatrywania autorek bądź po prostu kobiecy sposób ujmowania świata" (Kraskowska, 2003: 201-202). Podążając tropem sformułowań literaturoznawczyni, warto zapytać, czym jest $\mathrm{w}$ istocie owa wspomniana przez nią kobieca perspektywa oglądu rzeczywistości. Jest ona widoczna - zdaniem badaczki - w wyborze tematów oraz charakterystycznej dla krytyki feministycznej retoryki, nakierowanej na sprawy życia codziennego oraz kwestie cielesności. Kamila Budrowska stwierdza z kolei, że

[...] w przekazie kobiecym musi ujawnić się żeńska perspektywa narracyjna, specyficznie zaprojektowany, „życzliwy” wobec podjętych kwestii odbiorca oraz tematyka związana z kobiecym losem.

Inne wzmiankowane elementy - język, natężenie emocji, zapis specyficznych doświadczeń cielesnych są istotne, ale tylko jako dopełnienia tej sytuacji podstawowej (Budrowska, 2004: 289).

Niewątpliwie jakiekolwiek próby stworzenia zestawu cech koniecznych i wystarczających, które opisywałyby w sposób trwały i niepodważalny kobiecy reportaż podróżniczy, z góry określić należałoby mianem projektu utopijnego. Oprócz elementów genderowych na poetykę gatunku wpływa bowiem niezwykle wiele zróżnicowanych czynników, od konwencji aż po specyfikę wykorzystywanego medium, a nawet obowiązującą modę. Biorąc jednak pod uwagę fakt, że współcześnie teksty reportażowe wykazują wyraźne autobiograficzne zakorzenienie, wykraczając tym samym poza proste relacjonowanie zdarzeń, warto się zastanowić, czy i ewentualnie w jakim stopniu pewne zdefiniowane już na gruncie badań literaturoznawczych elementy pisarstwa kobiecego mogą znaleźć swoje odzwierciedlenie w przestrzeni reportażu. Pisane z kobiecej perspektywy teksty podróżnicze są bowiem często próbą zarejestrowania „kobiecego świata”. Eksponują osobę autorki, która odwołuje się do swej biografii, poglądów, emocji, uwypuklają żeńskie doświadczenie, „[...] żeńską codzienność, nadając im idiomatyczny i niepowtarzalny styl [...]" (Pekaniec, 2014: 22). Pokazują, że - by posłużyć się określeniem Anny Pekaniec -„„rzeczywistość nosi płciową sygnaturę" (2014: 22).

\section{Reporterki w podróży}

W poświęconej reportażowi podróżniczemu monografii Rejter wskazuje trzy etapy formowania się tego gatunku. W wieku XVI, XVII i XVIII do relacjonowania wydarzeń z odległych miejsc służyły najczęściej diariusze, itinerariusze oraz listy. 
W XIX stuleciu chętnie wykorzystywaną formą był list z podróży. Ostatni etap to powstanie reportażu podróżniczego, funkcjonującego w ścisłym powiązaniu z prasą drukowaną (Rejter, 2000: 8). Choć w pisywanych w każdym z tych okresów tekstach reportażowych bądź prereportażowych, będących zapisem odbywanej przez autora podróży, zdecydowanie dominował męski głos, wskazać warto nazwiska przynajmniej kilku profesjonalnych reporterek bądź pisarek-dziennikarek, które właśnie podróżowanie uczyniły głównym tematem swych prac.

Pisane „piórem niewieścim” reportaże i prereportaże pojawiały się już w wieku XIX, jednak ze względu na nieczęste wiązanie się kobiet z prasą teksty te należały do rzadkości. Jedną z najważniejszych ówczesnych reporterek była amerykańska dziennikarka Nellie Bly, która z polecenia Josepha Pulitzera pod koniec XIX stulecia udała się w podróż dookoła świata, pragnąc zamierzony cel wyprawy osiągnąć szybciej aniżeli bohater powieści Juliusza Verne'a pt. Wosiemdziesiąt dni dookoła świata.

Tworzone w wieku XVIII i w pierwszej połowie XIX stulecia przez autorki-podróżniczki teksty miały zazwyczaj charakter autobiograficzny i funkcjonowały raczej jako zapis osobistych doświadczeń aniżeli publicystyczna wypowiedź przygotowywana z myślą o publikacji na szpaltach prasy. W takim duchu redagowane były chociażby prace Mary Wollstonecraft (by przywołać tylko opublikowane w 1796 roku Letters Written During a Short Residence in Sweden, Norway and Denmark).

Zgoła odmiennie odczytywane mogą być natomiast teksty tworzone w drugiej połowie XIX i w początkowych dekadach XX wieku, wychodzące spod pióra takich autorek, jak: Izabella Bird, Mary Kingsley (autorka książki Travels in West Africa), Gabriela Zapolska (zamieszczająca w „Przeglądzie Tygodniowym” artykuły z Paryża), Ewa Dzieduszycka (podróżowała między innymi przez Indie, Palestynę, Rumunię, Grecję) czy Maria Konopnicka (owocem jej wyprawy do Włoch z 1883 roku były reportaże Wrażenia z podroży, z kolei zapisem doświadczeń zdobytych we francuskiej stolicy - szkice zebrane w tomie Na normandzkim brzegu). W tym okresie temat kobiecego podróżopisarstwa coraz szerzej powracał na kartach prasy, by wspomnieć chociażby brytyjski „The English Woman's Journal”, wychodzący w latach 1858-1864 (Korte, 2012: 158-174). Celem tych publikacji - jak zauważa Barbara Korte - nie było jednak właściwe dla reportażu zapoznanie czytelniczek ze światem, ale przede wszystkim opisanie indywidualnych doświadczeń kobiet, które mogły wówczas pozwolić sobie na tego rodzaju wyprawy.

Wiek XX to okres bardzo dynamicznych przekształceń, zwłaszcza jeśli chodzi o poetykę gatunku, ewoluującego w stronę formy intermedialnej, w sposób twórczy łączącej w sobie tekst, obraz i słowo. Współczesny kobiecy reportaż podróżniczy często opiera się na interferencji rozmaitych form przekazu, które - wzajemnie się dopełniając - współtworzą transmedialną opowieść o świecie. Taki charakter mają między innymi prace Martyny Wojciechowskiej, dystrybuującej swe reportaże za pośrednictwem zróżnicowanych platform komunikowania. Wpływ na przekształcenia reportażowej formy ma obecnie nie tylko zmieniający się rynek medialny, ale także idące za tym zmiany oczekiwań odbiorców. Jak pisze Natalia Wrzeszcz, 
[...] współczesne media prześcigają się w możliwościach dotarcia do jak najszerszej rzeszy odbiorców zainteresowanych poznaniem obcych kultur lub zjawisk. Powstają kanały i programy tematyczne, cykle reportaży, programy rozrywkowe i teleturnieje. Potrzeba ukazania, przybliżenia, daje miejsce pracy dziennikarzom-podróżnikom, którzy ze swojej pasji i chęci poznania „Innego" tworzą pewną opowieść o świecie. Opowieść ta wykracza jednak poza obszar reportażu literackiego, radiowego czy telewizyjnego. Staje się reporterską opowieścią transmedialną, która korzysta z różnych środków przekazu i nie byłaby możliwa, gdyby nie rozwój kultury konwergencji (Wrzeszcz, 2013: 204).

W tekstach reportażowych podróż dokumentowana jest najczęściej przy pomocy obrazowego języka i narracyjnego potencjału fotografii. Tak skonstruowane reportaże podróżnicze współczesnych trawelebrytek są nie tylko dziennikarską opowieścią o świecie, ale także rodzajem „produktu”, który ma w przestrzeni medialnej skutecznie konkurować z tworzonymi przez mężczyzn programami podróżniczymi. Kobiece reportaże przyciągają uwagę dynamicznie prowadzoną fabułą, silnym eksponowaniem osoby reporterki, nagromadzeniem przygód o nierzadko awanturniczym charakterze. Często poruszają wątki feministyczne, podejmują tematykę kobiecą, przyjmując kształt hybrydycznego trawelogu, łączącego elementy reportażu, komentarza i dziennika podróży.

\section{Inna podróż, Inna w podróży. Reportaże llony Wiśniewskiej}

W książkach reportażowych Wiśniewskiej dostrzec można wiele spośród wymienionych wyżej cech, pozwalających zaklasyfikować te teksty jako przykład kobiecego reportażu podróżniczego. Są one zapisem nierzadko prywatnych doświadczeń reporterki, eksplorującej terytorium pozostające ciągle jeszcze poza obszarem zainteresowań masowej turystyki. Fakt ten w istotny sposób wpłynął na kształt jej tekstów, które - choć przez wydawców i recenzentów klasyfikowane są zazwyczaj jako reportaże - w rzeczywistości łączą w sobie cechy charakterystyczne dla kilku gatunków. Opisana przez autorkę podróż do Norwegii czy na Grenlandię nie jest bowiem percypowana z charakterystycznego dla reportera dystansu, wynikającego najczęściej z konieczności zrealizowania materiału w określonym, wyznaczonym przez redakcję czasie. Autorka podąża tu raczej śladami innego reportera - Mariusza Wilka, wybierając nie tyle formułę reporterskiej tymczasowości, ile zakorzenienia (Żyrek-Horodyska, 2019: 261-276). Fakt ten pozwala piszącej uzyskać niezwykle interesującą i rzadką w tekstach reportażowych perspektywę osoby będącej jednocześnie "swoją" i "obcą", zaangażowaną uczestniczką i postronną obserwatorką zdarzeń.

Obrany przez dziennikarkę kierunek przez wzgląd na swą niedostępność i „egzotykę” wielokrotnie zwracał już uwagę reporterów oraz podróżników, by przywołać tylko prace brytyjskiej autorki Sary Wheeler, Jana Józefa Szczepańskiego (Zatoka białych niedźwiedzi) czy polskich autorów Aliny i Czesława Centkiewiczów. Pomysł Wiśniewskiej opiera się na stworzeniu tomów łączących w wymiarze intermedialnym reportażowy tekst z wykonanymi przez dziennikarkę fotografiami, dokumentującymi 
obserwowaną przestrzeń zazwyczaj w mikroskali. Charakterystyczną cechą jej prac jest silne nakierowanie na detal, którego opisy zdecydowanie przeważają nad (typowymi zwłaszcza dla dawniejszych tekstów reporterskich) panoramicznymi deskrypcjami kultury, zwyczajów czy bohaterów. Autorka koncentruje swą uwagę najczęściej na elementach potęgujących wrażenie "inności”, eksponujących odmienność topografii, uwypuklających swoisty „orientalizm” miejsca, którego opisy - jak deklarowała Wiśniewska w jednym z wywiadów - winny być tworzone bez zbytniej egzaltacji:

Założyłam sobie, że wszystko jest dla mnie ciekawe, ale nic nie podlega ocenie. To ważne, bo bardzo łatwo można wpaść w egzotyzującą narrację. Uummannaq w ogóle nie jest egzotyczne, dla jego mieszkańców jest normalne, a to ja jestem egzotyczna.

Jeden z bohaterów chciał pokazać żonie, że ludzie w Polsce też mają skośne oczy, zrobił mi zdjęcie. To było super, role się odwróciły. Mieszkańcy się ze mnie śmiali, bo zadawałam głupie pytania i to było bardzo dobre doświadczenie, wiesz, pokora to najlepsze, czego Północ cię uczy (Padoł, 2018).

Kulturowa odmienność jest elementem stanowiącym konstytutywną oś prowadzonej przez dziennikarkę narracji, wielokrotnie w swych autotematycznych wypowiedziach powracającej do refleksji nad tym, że postrzeganie Innego i bycie przez niego postrzeganym właśnie w kategoriach inności to dwa wzajemnie warunkujące się procesy. Reporterka ową kulturową „inność” rozważa na kilku poziomach, w sposób szczególny akcentując różnice językowe, społeczne i kulturowe. Wykorzystuje ją często jako rodzaj kotwicy, mającej przyciągnąć uwagę czytelnika. Zdarza się, że wzorem powieści sensacyjnej swą opowieść rozpoczyna od podania kilku interesujących szczegółów, których wyjaśnienie odbiorca będzie mógł odnaleźć dopiero w kolejnych rozdziałach tomu. Przykładowo Białe otwiera następujący obraz: „przyszłam więc i przez kolejne dni patrzyłam przez okno na miasteczko, w którym nie było ani jednego drzewa, ani jednego kota i ani jednej nocy" (Wiśniewska, 2014: 7); w reportażu Lud z kolei czytamy: Inuussutissarsiorsinnaajunnaarallarnersiutaarukkallartariaqaleraluarnersoruna, według jednej z książek, które pokazała mi któregoś dnia dziewczyna z domu dziecka, to najdłuższe słowo w tym języku" (Wiśniewska, 2018: 48-50).

Inność, jak twierdził Lévinas, winna zakładać otwarcie się na to, co nieznane. Wiśniewska przedstawia cel swej wyprawy jako miejsce, w którym wypełnienie Lévinasowskich postulatów nie powinno wydać się szczególnie skomplikowane, jako że Norwegia idee wielokulturowości uczyniła jednym ze swych flagowych projektów. W przestrzeni słynącej z ogromnego zaufania do obcych i otwarcia się na przybyszów traktowanie "Innego" radykalnie odbiega od tego, jak przedstawił je chociażby Kapuściński w swych tekstach poświęconych Afryce. Dziennikarka wielokrotnie podkreśla, że swą „inność” dzieli tu z wieloma mieszkańcami. Wyraźnie cechuje ją silna predylekcja do opowiadania o swym życiu przez pryzmat mówienia o innych:

Tam każdy skądś przyjechał - około 50 różnych narodowości, religii, poglądów i kultur. Społeczność przez lata wypracowała sobie struktury, dzięki którym to wszystko dobrze działa. 
Udało im się zbudować modelowe społeczeństwo wielokulturowe i dbają, żeby nie zostało zniszczone. Okazuje się, że w zasadzie wszyscy potrzebują kilku podstawowych rzeczy, jak wolność, dobre zarobki, przepływ myśli i tani alkohol, tylko trzeba stworzyć ku temu warunki. Ramy wyznacza norweska mentalność oparta na zaufaniu, a każdy z przyjezdnych dokłada coś od siebie (Stelmach, 2016).

Inność portretowana jest jako kategoria o niezwykle szerokim zakresie semantycznym. Wiśniewska w swym tomie stara się nakreślić możliwie wiele sposobów jej rozumienia, pokazując, że - wbrew upowszechnionym przez media masowe przekazom - nie musi się ona wiązać z dużym dystansem kulturowym, lecz może pojawić się nawet wśród mieszkańców tego samego kraju:

Kiedy mówiłam Norwegom z południa, że piszę książkę o Finnmarku, odpowiadali: o, to świetnie, chcielibyśmy ją przeczytać. Historia własnego kraju nie jest Norwegom znana, ale to wynika też po części z geografii - Norwegia to bardzo rozległy, długi kraj. Z południa na północ jest daleko i w tym kierunku nikt na wakacje nie jeździ (Padoł, 2016).

Na kartach książek Białe, Hen oraz Lud dziennikarka wielokrotnie powraca do tematu dotyczącego eksponowania kobiecości w przestrzeni, która pod wieloma względami zdaje się de facto tę kobiecość zakrywać i maskować. W tym kontekście włącza w obręb dziennikarskiej narracji także refleksję dotyczącą własnej tożsamości. Pisząca powraca do tego zagadnienia chociażby w kontekście strojów, stanowiących (zwłaszcza dla kobiet przyjeżdżających na Północ z innych krajów) element konstytuujący żeńską tożsamość. Wspominając spotkanie z tajską księżniczką, Wiśniewska trafnie opisuje swą pozorną tylko odmienność od zgromadzonych w sali kobiet:

Jestem jedyną nie-Tajką na tym spotkaniu. One na obcasach, ja w szarych skarpetkach, które w tym eleganckim towarzystwie są jeszcze bardziej szare i jeszcze grubsze. A na dodatek, przewyższając głową wszystkie zgromadzone tu kobiety, mam świadomość, że te moje stopy na pewno są tu największe. Podwijam palce i dygam, bo właśnie wchodzi księżniczka. I ku mojemu zaskoczeniu ona cała jest na szaro, w męskiej marynarce zapiętej na brzuchu, przykrótkich czarnych spodniach i półbutach bez wyrazu. Taką księżniczkę to ja rozumiem (Wiśniewska, 2014: 144).

W przytoczonym fragmencie wyraźnie uwypuklona została kobieca perspektywa, dostrzegalna w nakierowaniu uwagi na ubiór i kwestie cielesności. Nakreślona tu granica pomiędzy „innym” a „własnym” zostaje skutecznie unieważniona w sytuacji, gdy okazuje się, że owa Inna w surowym, północnym klimacie nosi podobne stroje i dalece odbiega od utrwalonych przez kulturę (zwłaszcza popularną) wyobrażeń.

Biorąc pod uwagę liczne tekstowe wskaźniki świadczące o wysokim stopniu personalizacji reportażowego dyskursu (pierwszoosobowa narracja, liczne odniesienia do biografii dziennikarki, częste sygnalizowanie przez nią własnych odczuć i stanów emocjonalnych), można - jak sądzę - zaryzykować stwierdzenie, że książki Wiśniewskiej są przykładem autoreportażu par excellence, wykazującego silną autotropiczną orientację. To teksty, w których dzieje reporterki ściśle splatają się z losami poszczególnych bohaterów. Nie oznacza to oczywiście, jakoby pisząca w trakcie swych reporterskich eksploracji całkowicie zarzuciła dążenie do obiektywizmu. Wiśniewska - 
wyjąwszy może fragmenty oddające fascynację obserwowaną przyrodą - unika jednak wyraźnego wartościowania, starając się w sposób możliwie precyzyjny oddać niuanse obserwowanej kultury.

Kobieca sygnatura dostrzegalna jest zwłaszcza w pojawiających się w reportażach licznych opisach natury. Quasi-literackie obrazy zórz polarnych, opisy idealnie przejrzystego powietrza, skromnej i permanentnie przegrywającej z zimnem przyrody przedstawione zostały w sposób niezwykle plastyczny i malarski; wręcz entuzjastyczny. Główną kategorią ekfrastycznego opisu staje się dla dziennikarki światło: jego obecność bądź brak, dominująca barwa, przekształcenia, ingerencja w życie człowieka. Wiśniewska często postrzega przyrodę w kategoriach estetycznego artefaktu. W tym przypadku uwidacznia się także wyjątkowa zdolność autorki do percypowania detali i polisensorycznego postrzegania świata:

Co roku czeka na to samo zaskoczenie, niezależnie od tego, jak długo się mieszka za kołem podbiegunowym. Światło wraca. Zwłaszcza jak przez kilka dni pada śnieg i są niskie chmury, a potem nagle niebo się wypogadza i okazuje się, że nadszedł dzień. Ale czy to jest radość? Bardziej zdziwienie, że to już. Ze tak szybko. Świat robi się za duży (Wiśniewska, 2014: 127).

Fascynacja topografią i krajobrazem w reportażach Wiśniewskiej zestawiona zostaje z licznymi opisami brutalności wobec zwierząt, obrazami polowań, psich zaprzęgów, zabijania niedźwiedzi. Zwłaszcza w tych fragmentach autorce trudno zachować dystans i obiektywizm. Odsłaniają one wyraźnie postawę piszącej, która nie chce li tylko pozostawać świadkiem zdarzeń, lecz ma również ambicję bycia ich wnikliwą komentatorką. W tym przypadku kobieca wrażliwość i niezrozumienie dla brutalnych praw obowiązujących w surowym krajobrazie Północy wielokrotnie zdają się dominować nad racjonalnym, reporterskim oglądem świata.

Reportaże literackie Wiśniewskiej są zapisem szeroko zakrojonego reporterskiego projektu, którego centralnym elementem staje się podróż do możliwie najbardziej wysuniętych na północ miejsc Europy. Dziennikarka decyduje się na częstą zmianę lokalizacji. Podróżuje od Spitsbergenu przez Finnmark aż po Grenlandię. Podejmowane przez nią próby zakorzenienia zderzane są ze stale towarzyszącym autorce poczuciem odmiejscowienia. Jej wyprawy nie są bowiem immanentnie związane z pragnieniem przygotowania dziennikarskiego materiału, lecz mają także bardzo silne powiązanie $z$ biografią piszącej. Sama podróż była dla niej bowiem pierwotnie nie tyle początkiem reporterskich eksploracji, ile sposobem na poradzenie sobie w trudnym momencie życia. W otwierającym tom Białe akapicie czytamy:

Na Spitsbergen przyleciałam pierwszy raz w sierpniu 2009 roku. Wiedziałam, że muszę na północ, a Longyearbyen - największa osada na wyspie - leżało możliwie najdalej. Arktyczne lato było chłodniejsze od tego europejskiego o jakieś trzydzieści stopni, więc dało się zebrać myśli. Bryły, kolory, odgłosy, wszystko było inaczej (Wiśniewska, 2014: 7).

W tym przypadku bieg podróży pozostaje bardzo mocno spleciony z biegiem życia. Spitsbergen staje się bowiem początkowo przede wszystkim sprzyjającym kontemplacji celem ucieczki, który pozwoli z dystansu spojrzeć na ważne kwestie. Reporterka 
wielokrotnie wplata w tekst aluzje do życia prywatnego; zarówno tego pozostawionego w Polsce, jak również tego, które zaczęła układać sobie w Norwegii.

Choć reportaże Wiśniewskiej są opowieścią o podróży na kraniec europejskiej mapy, W rzeczywistości daleko im do historii „kobiety na krańcu świata”. Wiele spośród zamieszczonych w książkach Białe, Hen i Lud fragmentów ma charakter poetycki i impresyjny. Przykładowo, o swej podróży na Grenlandię Wiśniewska pisała:

Pierwsze dni to układanie puzzli bez pudełka. Zamarznięte morze reguluje długość fal po swojemu, przez co w jaskrawym świetle widać tylko pulsujące barty podstawowe domów przytwierdzonych betonem do skał. Im bardziej mruży się oczy, tym więcej kolorów ubywa, migają tylko białe kwadraty na białym tle (Wiśniewska, 2018: 19).

Przytoczony tu cytat niewątpliwie daleki jest od reporterskiej precyzji i dokumentarności. Ma raczej charakter literackiej impresji. Optyka piszącej nie jest w tym przypadku wyłącznie skierowana na zewnątrz. Krajobraz staje się raczej wypadkową rzeczywistej, materialnej przestrzeni i sposobu jej percypowania przez patrzącą; zostaje tym samym niejako zredukowany do określonej wizji i jako taki de facto wymyka się obiektywnemu poznaniu. Autorka, choć wielokrotnie dowiodła już tego, jak doskonałą jest obserwatorką, tym razem, zdając sobie sprawę z niewyrażalności dziennikarskiego dyskursu, stara się opowiedzieć o percypowanym obszarze przy pomocy metafor i porównań przybliżających czytelnikowi niezwykłość obserwowanych krajobrazów, a jednocześnie pozostawiających element tajemniczości i niedopowiedzenia.

Pod względem genologicznym książki Wiśniewskiej wydają się łączyć elementy reportażu z poetyką redagowanego z dużą dokładnością dziennika podróży, w którym autorka scala dziennikarską opowieść o ludziach i wydarzeniach z obszerną refleksją poświęconą pokonywaniu wytyczonej drogi. W tym ujęciu reporterka - by posłużyć się określeniem Wilka - łącząc narrację z autonarracją, wydeptuje własną tropę. Prowadzi ona zazwyczaj do miejsc, które wymykają się przewodnikowym deskrypcjom, a dla polskiego odbiorcy pozostają najczęściej nieodkryte. Czytelnik otrzymuje szczegółowe wytyczne, w jaki sposób autorka dotarła do poszczególnych miejsc, kogo napotkała na trasie wyprawy, jaki był cel jej przedsięwzięcia, jakie trudności spotkały ją podczas podróży.

Obok precyzyjnych geograficznych lokalizacji pojawiają się w reportażu także fragmenty silnie zmetaforyzowane, mające opowiedzieć odbiorcy o nieznanej mu przestrzeni przy wykorzystaniu bliskich mu kontekstów kulturowych. Dążąc do realizacji tego założenia, na kartach książki Lud dziennikarka kreśli nietypową mapę Grenlandii:

Do Tokio dziesięć, do Rzymu pięć czterdzieści, do bieguna północnego tylko trzy godziny z kwadransem. Jeśli przyjąć, że Grenlandia rzeczywiście kształtem przypomina niedźwiedzia polarnego, to od kości udowej w Kangerlussuaq do prawej przedniej łapy w Uummannaq w linii prostej jest zaledwie czterysta kilometrów, mimo że na miejsce dociera się stąd w dwadzieścia godzin (Wiśniewska, 2018: 13). 
Trudno o bardziej plastyczny i obrazowy sposób prezentowania mapy, która w tym wypadku zdecydowanie wymyka się tradycyjnym reporterskim deskrypcjom. Przytoczony tu opis niewiele ma wspólnego ze stylem stricte dziennikarskim, zbliża się natomiast do eseju czy felietonu. Obok prostego informowania Wiśniewska za sprawą niestandardowych, zmetaforyzowanych konstrukcji dąży bowiem także do realizacji funkcji ekspresyjnej; pragnie wywołać w czytelniku wrażenie niezwykłości, wyjątkowości opisywanego miejsca.

Podróż jest dla reporterki między innymi spotkaniem z językiem, w którym Wiśniewska z uwagą poszukuje słów nieprzetłumaczalnych na język polski, przypisanych niejako do konkretnego miejsca na mapie. Wielokrotnie narracyjnym impulsem stają się dla niej słowa nieprzekładalne; generujące pracę wyobraźni bądź pracę pamięci. Poprzez zgłębianie niezwykłości języka autorka stara się wyeksponować odmienność opisywanej przestrzeni, a jednocześnie uwypuklić fakt, że reportaż jest nie tylko reprezentacją, ale także konstrukcją. W Białym powiada:

Zanim śnieg się stopi, pozostaje to bezpieczne ciepło w hytcie, które Norwegowie nazywają kos, a wymawiają „kus”. Kus oznacza wszystko, co kojarzy się z domem, ciszą, smacznym jedzeniem i miłością. Jak uczucie, kiedy się wchodzi z zimnego do domu, gdzie pachnie kąpielą i miękką skórą. To jest o wiele więcej niż przytulenie. Trudno to w ogóle przetłumaczyć (Wiśniewska, 2014: 116-117).

Na kartach Hen notuje:

Słowo hen w norweskim, jak w polskim, odnosi się do odległości, tyle że tutaj to może być równie dobrze po drugiej stronie globu, jak i za rogiem. Hen to równocześnie daleko i blisko (Wiśniewska, 2016: 43-44).

W Ludzie z kolei czytamy:

Mamy na przykład takie słowo silaquarpoq. Sila to jednocześnie pogoda i świadomość. Silaqarpoq to cecha człowieka, który czuje otoczenie, jest obecny duchem w danym momencie (Wiśniewska, 2018: 52).

Dziennikarka, podążając tu niejako śladem Kapuścińskiego, odgrywa rolę tłumaczki kultur (Kapuściński, 2007: 7-16), stara się sportretować odmienności opisywanego obszaru przez pryzmat języka, który tę rzeczywistość opisuje. Co istotne, tworząc tekst, który niejako ex definitione winien spełniać funkcje poznawcze, Wiśniewska nie dąży za wszelką cenę do precyzji wypowiedzi. Istotne w jej sposobie portretowania odwiedzanych miejsc są emocje, przez pryzmat których stara się nakreślić kulturowe odrębności, a jednocześnie wyraźnie zaakcentować swą rolę w konstruowanej narracji. 


\section{Posumowanie}

Jak pokazały nakreślone w niniejszym szkicu ustalenia, książki Wiśniewskiej wpisują się w model podróżniczego reportażu literackiego, znacząco wykraczając jednak poza jego granice. Reporterka odrzuca przede wszystkim tak charakterystyczne dla ponowoczesnych mediów założenie, że dziennikarz w każdym miejscu pozostaje tylko na chwilę, a poszczególne etapy jego pracy wyznaczane są przez pragnienie zdobycia kolejnego newsa. Wbrew obowiązującym zwłaszcza w mediach elektronicznych standardom, często spychającym analizowany tu gatunek w kierunku trawelebryckiej, intermedialnej narracji, prace wspomnianej autorki czerpią raczej z dorobku dawnych mistrzów, kładących nacisk przede wszystkim na dokładny, rzetelny i wieloaspektowy opis rzeczywistości; akcentujących nie tylko obserwację, ale i uczestnictwo; eksponujących w równej mierze cel podróży, co drogę do jego osiągnięcia.

Pozostaje jeszcze zapytać, czy możliwe jest spojrzenie na reportaże Wiśniewskiej jak na teksty będące zapisem utrwalonego w warstwie obrazów, opisów i komentarzy kobiecego doświadczenia. Niewątpliwie w pracach tej dziennikarki dostrzec można liczne ślady autorskiej obecności, a perspektywa kobiecego spojrzenia uwidacznia się jednocześnie na kilku poziomach. Dominującą cechą dyskursu Wiśniewskiej pozostaje wrażliwość oraz wyraźnie wpisany w tekst rodzaj estetycznego widzenia rzeczywistości. Analizowane w niniejszym szkicu reportaże są połączeniem wysoce subiektywnych relacji z podróży z elementami opowieści autobiograficznej, stanowiącej niejako ramę narracyjną dla przedstawianych w tekstach wydarzeń. Kobiece wcielenie homo viator to - w świetle ustaleń Wiśniewskiej - postać, która permanentnie łączy refleksję nad podróżowaniem z wnikliwą introspekcją. Choć Białe, Hen i Lud pozostają przede wszystkim dokumentarną, dziennikarską opowieścią o inności, która zawsze pozostaje wzajemna, są one także zapisem indywidualnych doświadczeń autorki, odgrywającej jednocześnie rolę przewodniczki po opisywanym terytorium oraz pełnoprawnej bohaterki tekstu. Ta podwójna optyka nie pozostaje bez wpływu na kształt reportażowej narracji, która współcześnie coraz częściej przyjmuje formę opowieści hybrydycznej, rozsadzającej ramy tradycyjnej genologii dziennikarskiej.

\section{Bibliografia}

Braidotti R. (2009), Podmioty nomadyczne. Ucieleśnienie i różnica seksualna w feminizmie wspótczesnym, przeł. A. Derra, Wydawnictwa Akademickie i Profesjonalne, Warszawa.

Budrowska K. (2004), Kobieta w procesie literackiego komunikowania. Rozważania teoretycznoliterackie i nie tylko, „Teksty Drugie”, nr 1-2, s. 283-290.

Cixous H. (1993), Śmiech Meduzy, przeł. A. Nasiłowska, „Teksty Drugie”, nr 4/5/6, s. $147-166$. 
Czapliński P. (2010), Kobieta jako inny. Literatura wobec ponowoczesności, [w:] G. Borkowska, L. Wiśniewska (red.), Beatrycze i inne. Mity kobiet w literaturze i kulturze, Wydawnictwo Słowo/obraz, terytoria, Gdańsk.

Czermińska M. (1982), Postawa autobiograficzna, [w:] J. Błoński, S. Jaworski, J. Sławiński (red.), Studia o narracji, Zakład Narodowy im. Ossolińskich, Wrocław.

Janion M. (2006), Kobiety i duch inności. Wydawnictwo Sic!, Warszawa.

Kaliszewski A., Żyrek-Horodyska E. (2019), Kasandry i Amazonki. W kręu kobiecego reportażu wojennego, Wydawnictwo Uniwersytetu Jagiellońskiego, Kraków.

Kapuściński R. (2004), Spotkanie z Innym jako wyzwanie XXI wieku, Universitas, Kraków.

Kapuściński R. (2006), Ten Inny, Znak, Kraków.

Kapuściński R. (2007), Tłumacz-postać XXI wieku, [w:] B. Dudko (red.), Podróże z Ryszardem Kapuścińskim. Opowieści trzynastu tłumaczy, Znak, Kraków.

Kapuściński R. (2016), Busz po polsku, Czytelnik, Warszawa.

Korte B. (2012), Travel Writing in "The English Woman's Journal" (1858-1864). An Area of Leisure in the Context of Women's Work", "Victorian Periodicals Review", No 2, s. 158-174.

Kraskowska E. (2003), Piórem niewieścim. Z problemów prozy kobiecej dwudziestolecia wojennego, Wydawnictwo Naukowe UAM, Poznań.

Kuros-Kowalska K. (2015), Sposoby autoprezentacji kobiet i mężzyzn na przykładzie reportaży podróżniczych Wojciecha Cejrowskiego oraz Beaty Pawlikowskiej, [w:] I. Loewe, E. Tyc, A. Kalisz (red.), Dyskurs autopromocyjny i jego wspótczesne odstony, Wydawnictwo Uniwersytetu Śląskiego, Katowice.

Lévinas E. (2002), Catość i nieskończoność. Esej o zewnętrzności, przeł. M. Kowalska, PWN, Warszawa.

Nawrocka E. (2002), Osoba w podróży. Podróże Marii Dąbrowskiej, Wydawnictwo Uniwersytetu Gdańskiego, Gdańsk.

Nycz R. (1981), Prywatna księga różności, „Teksty”, nr 4-5, s. 203-233.

Nycz R. (2001), Literatura jako trop rzeczywistości. Poetyka epifanii w nowoczesnej literaturze polskiej, Universtias, Kraków.

Odwaga jest kobieta (2014), oprac. M. Szarejko, PWN, Warszawa.

Padoł E. (2016), Ilona Wiśniewska: Z tq Pótnocą chyba chodzi o światto, https://kultura.onet. pl/wiadomosci/ilona-wisniewska-z-ta-polnoca-chyba-chodzi-o-swiatlo-wywiad/ qfe9gzc [dostęp: 18.04.2019].

Padoł E. (2018), Ilona Wiśniewska: W Grenlandii rozumiesz, że jesteś paprochem do wygumkowania na zdjecciu, https://kultura.onet.pl/wywiady-i-artykuly/ilona-wisniewska-wgrenlandii-rozumiesz-ze-jestes-paprochem-do-wygumkowania-na/rd309lp [dostęp: 20.04.2019].

Pekaniec A. (2014), Literatura dokumentu osobistego kobiet. Ewolucja teorii, zmiany praktyk lekturowych, „Autobiografia. Literatura. Kultura. Media”, nr 1, s. 13-28. 
Rejter A. (2000), Kształtowanie się gatunku reportażu podróżniczego w perspektywie stylistycznej i pragmatycznej, Wydawnictwo UŚ, Katowice.

Stelingowska B. (2018), „Wojna nie ma w sobie nic z kobiety”. Wokót reportażu Swiettany Aleksijewicz, [w:] M. Kubiak, R. Wróblewski (red.), Oblicza współczesnych wojen, Oficyna Wydawnicza ASPRA-JR, Warszawa-Siedlce.

Stelmach M. (2016), Polka w Norwegii: W trudnych warunkach jest mniej bodźców, więc tatwiej być samemu ze soba, http://www.wysokieobcasy.pl/wysokie-obcasy/1,53662,20403010,zycie-na-spitsbergenie-w-trudnych-warunkach-jest-mniej -bodzcow.html [dostęp: 18.04.2019].

Tischner J. (2004), Inny, „Znak”, nr 584, s. 16-29.

Walęciuk-Dejneka B. (2016), Kobiece doświadczanie drogi: "ja" w podróży. Rozważania na podstawie Wspomnień Anny Dostojewskiej, „Prace Literaturoznawcze”, nr IV, s. 99-113.

Wiśniewska I. (2014), Białe. Zimna wyspa Spitsbergen, Czarne, Wołowiec.

Wiśniewska I. (2016), Hen. Na pótnocy Norwegii, Czarne, Wołowiec.

Wiśniewska I. (2018), Lud. Z grenlandzkiej wyspy, Czarne, Wołowiec.

Wrzeszcz N. (2013), Blondynki na krańcu świata. Kobieca opowieść o Czarnym Lądzie, „Annales Universitatis Paedagogicae Cracoviensis. Studia de Cultura”, t. 5, s. 203-214.

Żyrek-Horodyska E. (2019), Kartografowie codzienności. O przestrzeni (w) reportażu, Instytut Dziennikarstwa, Mediów i Komunikacji Społecznej UJ, Kraków. 